\title{
Insight into Saturated Hydraulic Conductivity of Cemented Paste Backfill Containing Polycarboxylate Ether-Based Superplasticizer
}

\author{
Sada Haruna and Mamadou Fall *
}

check for updates

Citation: Haruna, S.; Fall, M. Insight into Saturated Hydraulic Conductivity of Cemented Paste Backfill Containing Polycarboxylate Ether-Based Superplasticizer. Minerals 2022, 12, 93. https:// doi.org/10.3390/min12010093

Academic Editor: Abbas Taheri

Received: 18 December 2021

Accepted: 9 January 2022

Published: 14 January 2022

Publisher's Note: MDPI stays neutral with regard to jurisdictional claims in published maps and institutional affiliations.

Copyright: (c) 2022 by the authors. Licensee MDPI, Basel, Switzerland. This article is an open access article distributed under the terms and conditions of the Creative Commons Attribution (CC BY) license (https:/ / creativecommons.org/licenses/by/ $4.0 /)$.
Department of Civil Engineering, University of Ottawa, 161 Colonel by, Ottawa, ON K1N 6N5, Canada; sharu023@uottawa.ca

* Correspondence: mfall@uottawa.ca; Tel.: +1-613-562 5800 (ext. 6558); Fax: +1-613-562-5173

\begin{abstract}
Recycling of tailings in the form of cemented paste backfill (CPB) is a widely adopted practice in the mining industry. Environmental performance is an important design criterion of $\mathrm{CPB}$ structures. This environmental performance of CPB is strongly influenced by its saturated hydraulic conductivity (permeability). Superplasticizers are usually added to improve flowability, but there is a limited understanding of their influence on the hydraulic properties of the CPB. This paper presents new experimental results on the variations of the hydraulic conductivity of $\mathrm{CPB}$ containing polycarboxylate-based superplasticizer with different compositions and curing conditions. It is found that the hydraulic conductivity of the CPB decreases with the addition of superplasticizer, which is beneficial to its environmental performance. The reduction is largely attributable to the influence of the ether-based superplasticizer on particles mobility and cement hydration. Moreover, both curing temperature and time have correlations with the hydraulic conductivity of CPB containing superplasticizer. In addition, the presence of sulfate and partial replacement of PCI with blast furnace slag reduces the hydraulic conductivity. The variations are mainly due to the changes in the pore structure of the $\mathrm{CPB}$. The new results discussed in this manuscript will contribute to the design of more environmental-friendly $\mathrm{CPBs}$, which is essential for sustainable mining.
\end{abstract}

Keywords: cemented paste backfill; tailings; hydraulic conductivity; superplasticizer; environmental performance; acid mine drainage

\section{Introduction}

Cemented paste backfill (CPB) offers an efficient means of mine waste (i.e., tailings) valorization both environmentally and economically. The tailings, which is the waste from the milling process, are combined with a binder, water, and chemical admixtures, when applicable, and used to fill the voids created from the mining. These mine tailings usually contain hazardous chemical compounds and would otherwise be impounded on the land posing a grave threat to the environment as well as human lives. In addition, the CPB technology is economically advantageous because it improves the productivity of ore retrieval during mining [1-6]. Moreover, binder inclusion ensures that the backfill becomes self-supporting after a short period, making the excavation of adjacent ore body possible. To ensure optimum performance of $\mathrm{CPB}$, its early-age and long-term behaviors have to be incorporated in the design [7-10]. Some of these properties are responsible for its environmental performance (e.g., leachability, susceptibility to acid mine drainage) and are largely associated with hydraulic conductivity [11,12].

A notable environmental issue of great concern to the mining industry is the acid mine drainage (AMD). The term is used to describe the production of acidic water from sulfiderich material when exposed to oxygen and water [13,14]. Although it occurs naturally, AMD is more prevalent across mining sites, whether operational or abandoned, due to increased exposure of sulfides by the mining operations [15]. This is because sulfide minerals occur as 
accessory minerals along with many other valuable minerals targeted by mining [16-18]. In most cases, the sulfide compounds are inert due to the absence of molecular oxygen in the rock mass [19]. Upon exposure to the atmosphere through mining, they react with water and oxygen to produce sulfuric acid in the presence of acidophilic microorganisms [19]. For example, oxidation of pyrite $\left(\mathrm{FeS}_{2}\right.$ - one of the most commonly occurring sulfide minerals) produces sulfuric acid as well as ferric iron under favorable conditions [20]. When produced in $\mathrm{CPB}$, these compounds may leach into nearby groundwater body, thereby leading to contamination. The susceptibility of CPBs to AMD is largely a function of the oxidation potential of the tailings that make up the CPB. Subsequently, this oxidation potential is not only controlled by the kinds and amount of sulfide minerals contained in the backfill material, but also by the facility with which fluids (water and oxygen) gain access to and flow through the matrix of the backfill material. In other words, this oxidation potential also depends on the permeation properties of the CPB. These properties can be evaluated using information about the hydraulic conductivity of the CPB [21].

Furthermore, the leachability of the CPB is another potential environmental concern because of the possible presence of harmful ingredients, such as heavy metals and/or other contaminants, in the CPB materials. As mines are closed and pumping is stopped, the groundwater water table rises back to its natural level by the upward migration of water through the backfill mass [22]. The flow rate of the groundwater through the backfill structure is a function of the hydraulic conductivity of the CPB mass. In other words, the hydraulic conductivity is the main parameter that governs the leaching capacity and transport of contaminants through the CPB structure to groundwater $[21,23]$.

A number of studies have been conducted in recent years to understand the hydraulic conductivity behavior of CPB [21,23-27]. The variation of the hydraulic conductivity in the CPB has been attributed to different factors such as tailings fineness [28], binder content [11,21], binder types [21,24], curing time and temperature [21,29], and sulfate content [21]. However, none of the studies investigated the hydraulic conductivity of the CPB in the presence of high range water reducing admixtures, commonly known as superplasticizers. The use of superplasticizers in CPB is becoming popular in the mining industry; therefore, understanding their effects on the key permeation properties of the $\mathrm{CPB}$ is of paramount importance for the reasons discussed above.

Superplasticizers are added to CPB in order to improve its workability and/or flowability without exceeding required mixing water for optimal performance. These admixtures enhance the fluidity of cementitious materials based on the characteristics of their organic polymer molecules [30]. The soapy molecules surround the solid particles in the cementitious material, causing dispersion through electrostatic and steric forces [31,32]. The major types of superplasticizers used are based on naphthalene, lignosulfonate, or polycarboxylate compounds [33,34]. The polycarboxylate-based superplasticizers are known to affect cement hydration reaction [35] and may behave differently in the presence of sulfide minerals $[36,37]$ typically found in tailings. Despite these interactions, there has not been any scientific research to understand the hydraulic conductivity behavior of CPB containing this type of admixture.

In light of what is discussed above, the objective of this study was therefore to study the changes in hydraulic conductivity of CPB admixed with polycarboxylate ether-based superplasticizer.

\section{Materials and Methods}

\subsection{Materials Used}

\subsubsection{Tailings}

Pure ground silica tailings (ST) and natural tailings (NT) from a gold mine in Canada were used as the main constituents of the CPB in this study. With $99.8 \mathrm{wt}$.\% quartz and grain-size distribution similar to the average from various mines in Canada (Figure 1), the ST is a good medium for laboratory experiments to minimize uncertainties. This is because it does not contain reactive minerals and, therefore, the observed variation would 
be as a result of the treatments the $\mathrm{CPB}$ is subjected to. Table 1 shows basic characteristics of ST and NT. It can be observed from Figure 1 that the ST contains about $45 \mathrm{wt} . \%$ fines (i.e., diameter $<20 \mu \mathrm{m}$ ) and can thus be classified as medium tailings. On the other hand, the NT contains several mineral compounds such as albite and pyrite (determined by XRD analysis), as shown in Table 2. It was incorporated in the study to have a better understanding of the practicability of the tests since it is a better representation of the tailings used in practice. The percentage of the fines in the NT is about $36 \mathrm{wt} . \%$, so it is also classified as medium tailings. To maintain uniform a water-to-cement ratio in the $\mathrm{CPB}$, the natural water content in the NT was calculated and then incorporated in determining the mass of the mixing water.

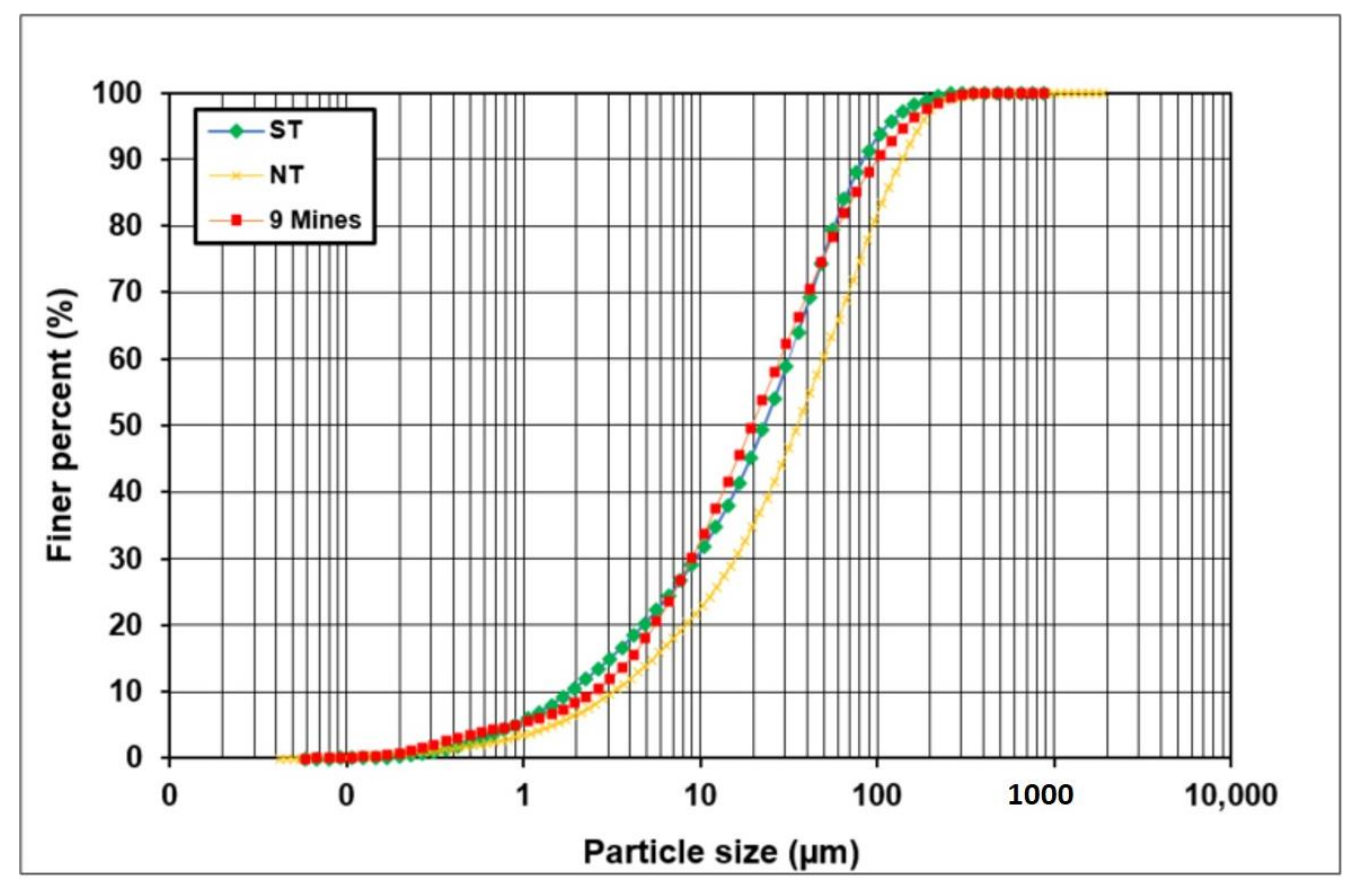

Figure 1. The grain size distribution of the tailings used in this research with an average of 9 Canadian mine tailings (grain size distribution determined by means of laser particle size distribution analyzer.

Table 1. Characteristics of the tailings used and the coarse-grained sand.

\begin{tabular}{cccccc}
\hline \multirow{2}{*}{ Material } & \multicolumn{5}{c}{ Characteristics } \\
\cline { 2 - 6 } & $\mathbf{G}_{\mathbf{s}}$ & $\mathbf{D}_{\mathbf{1 0}}(\mu \mathrm{m})$ & $\mathbf{D}_{\mathbf{3 0}}(\boldsymbol{\mu m})$ & $\mathbf{D}_{\mathbf{5 0}}(\mu \mathrm{m})$ & $\mathbf{D}_{\mathbf{6 0}}(\boldsymbol{\mu m})$ \\
\hline $\mathrm{ST}$ & 2.7 & 1.9 & 9.0 & 22.5 & 31.5 \\
\hline NT & 3.1 & 3.2 & 15.8 & 35.5 & 49.5 \\
\hline Note: Gs: specific gravity. & & &
\end{tabular}

Table 2. Mineralogical composition of the tailings used (determined by XRD analysis in this study).

\begin{tabular}{|c|c|c|c|c|c|c|c|c|c|c|c|c|c|}
\hline \multirow{2}{*}{ Tailings } & \multicolumn{13}{|c|}{ Mineral } \\
\hline & Quartz & Albite & Dolomite & Calcite & Chlorite & Magnetite & Pyrite & Talc & Pyrrhotite & Pyrite & Spinel & Others & Total \\
\hline $\begin{array}{c}\mathrm{ST} \\
\text { (wt.\%) }\end{array}$ & 99.8 & - & - & - & - & - & - & - & - & - & - & 0.2 & 100 \\
\hline $\begin{array}{c}\mathrm{NT} \\
(w \mathrm{wt} \%)\end{array}$ & 15 & 32.8 & 15 & 4.2 & 16.1 & 2.4 & 1 & 7 & 1.8 & 0.3 & 1.8 & 2.6 & 100 \\
\hline
\end{tabular}

\subsubsection{Binders}

The main binder used in the preparation of the CPB samples is Portland cement type $\mathrm{I}$ (PCI). Because it accounts for a large portion of the $\mathrm{CPB}$ production cost, alternative 
pozzolans are often used as a replacement. For that reason, tests were conducted on $\mathrm{CPB}$ containing ground blast furnace slag (BFS) and fly ash (FA) as a partial replacement of PCI with a blending ratio of 50/50. BFS and FA were provided by Lafarge Canada Inc. The properties of the three binders are given in Table 3.

Table 3. Physical and chemical properties of the binders.

\begin{tabular}{|c|c|c|c|c|c|c|c|c|}
\hline Binder Type & $\begin{array}{c}\mathrm{MgO} \\
(\mathrm{wt} . \%)\end{array}$ & $\begin{array}{c}\mathrm{CaO} \\
(w t . \%)\end{array}$ & $\begin{array}{c}\mathrm{SiO}_{2} \\
(w \mathrm{t} . \%)\end{array}$ & $\begin{array}{l}\mathrm{Al}_{2} \mathrm{O}_{3} \\
\text { (wt. } \% \text { ) }\end{array}$ & $\begin{array}{l}\mathrm{Fe}_{2} \mathrm{O}_{3} \\
\text { (wt. } \% \text { ) }\end{array}$ & $\begin{array}{c}\mathrm{SO}_{3} \\
\text { (wt. } \%)\end{array}$ & Relative Density & $\begin{array}{c}\text { Specific Surface } \\
\text { Area }\left(\mathrm{cm}^{2} / \mathrm{g}\right)\end{array}$ \\
\hline PCI & 2.65 & 62.82 & 18.03 & 4.53 & 2.70 & 3.82 & 3.1 & 1300 \\
\hline $\mathrm{FA}$ & 5.58 & 21.47 & 38.06 & 19.45 & 5.33 & 2.7 & 2.6 & 2200 \\
\hline BFS & 10.98 & 41.14 & 34.32 & 9.54 & - & 3.87 & 2.8 & 2100 \\
\hline
\end{tabular}

\subsubsection{Chemical Admixture}

A polycarboxylate ether-based Superplasticizer, Master Glenium 7500, made by Badische Anilino und Soda Fabrik (BASF), was used as the water reducing admixture in the preparation of the CPB. It is widely used in the backfill construction industries for the improvement of workability and/or flowability. It complies with the ASTM standard C494/C494M for high-range water-reducing admixture. The slump (determined according to ASTM C143/C143M-15a [38] of the CPB mixes containing $0 \%$ and $0.125 \%$ of the superplasticizer were found to be 22.2 and $29.6 \mathrm{~cm}$, respectively. The proportion used was chosen based on common practice in Canada.

\subsubsection{Mixing Water}

Ordinary tap water was used for mixing the constituents of the CPB. When admixture and/or sulfate were to be added, an appropriate mass was dissolved in the water before being added to the solids.

\subsection{Sample Preparation and Curing}

CPB specimens with tailings and different compositions of superplasticizer, binders, sulfate, and water-to-cement ratio were prepared based on the experimental plan given in Table 4. For each mixture, the solids (i.e., tailings and binders) were first blended in a mechanical mixer for about 2 min after which the water containing the admixture and/or sulfate was added. The materials were then mixed further for an additional 5 min to achieve homogeneity. It is important to mention that the ingredients were always pre-weighed and kept in a temperature-controlled chamber (an oven or a refrigerator) over a period of at least $24 \mathrm{~h}$ to achieve the desired temperature. In addition, the same chamber was used during the mixing phase. Prepared CPB was then cast into airtight cylindrical molds with a diameter of $5 \mathrm{~cm}$ and a height of $10 \mathrm{~cm}$. The molds were agitated gently to remove air bubbles from the CPB. They were then sealed and kept in the temperature-control chamber before testing. The specimens were cured for 1, 7, 28, 60, and 90 days. The CPB preparation method adopted in this study is similar to that used in numerous previous studies (e.g., [39-42] ).

\subsection{Hydraulic Conductivity Test}

The saturated hydraulic conductivity (permeability) of cured CPB specimens was determined using Tri-Flex 2 flexible wall permeameter in accordance with ASTM D5084-16 standard. A constant head method was adopted with a pressure difference between the inflow and outflow being 10 Psi $(69 \mathrm{kPa})$. Full saturation was achieved prior to the test by applying backpressure after bridging the inflow and outflow burettes until the flow through the specimen becomes constant. Each test was repeated twice to ensure reproducibility of results. 
Table 4. Experimental plan showing the composition of CPB samples.

\begin{tabular}{|c|c|c|c|c|c|c|c|c|c|}
\hline Sample Name & Tailings Type & $\begin{array}{c}\text { Binder Content } \\
(\%) *\end{array}$ & $\begin{array}{l}\text { PCI in the } \\
\text { Binder (\%) }\end{array}$ & $\begin{array}{l}\text { FA in the } \\
\text { Binder }(\%)\end{array}$ & $\begin{array}{l}\text { BFS in the } \\
\text { Binder (\%) }\end{array}$ & W/C Ratio & $\begin{array}{l}\text { Superplasticizer } \\
\text { Content }(\%)\end{array}$ & $\begin{array}{l}\text { Sulfate Content } \\
\text { (ppm) }\end{array}$ & $\begin{array}{c}\text { Curing } \\
\text { TemPerature }\left({ }^{\circ} \mathrm{C}\right)\end{array}$ \\
\hline \multicolumn{10}{|c|}{ A. Time-dependent evolution of hydraulic conductivity } \\
\hline CPB-ST-0.0\% & ST & 4.5 & 100 & 0 & 0 & 7.35 & 0.0 & 0 & 20 \\
\hline CPB-NT-0.125\% & NT & 4.5 & 100 & 0 & 0 & 7.35 & 0.125 & 0 & 20 \\
\hline \multicolumn{10}{|c|}{ B. Effect of curing temperature on hydraulic conductivity } \\
\hline CPB-0.125-Tem 2 & ST & 4.5 & 100 & 0 & 0 & 7.35 & 0.125 & 0 & 2 \\
\hline CPB-0.125-Tem 35 & NT & 4.5 & 100 & 0 & 0 & 7.35 & 0.125 & 0 & 35 \\
\hline \multicolumn{10}{|c|}{ C. Effect of binder type on the hydraulic conductivity } \\
\hline CPB-0.125-PCI & ST & 4.5 & 100 & 0 & 0 & 7.35 & 0.125 & 0 & 20 \\
\hline $\begin{array}{l}\text { CPB-0.125- } \\
\text { PCI/FA }\end{array}$ & ST & 4.5 & 50 & 50 & 0 & 7.35 & 0.125 & 0 & 20 \\
\hline $\begin{array}{l}\text { CPB-0.125- } \\
\text { PCI/BFS }\end{array}$ & ST & 4.5 & 50 & 0 & 50 & 7.35 & 0.125 & 0 & 20 \\
\hline \multicolumn{10}{|c|}{ D. Effect of W/C ratio on the hydraulic conductivity } \\
\hline $\begin{array}{c}\text { CPB-0.125-W/C } \\
7.35\end{array}$ & St & 4.5 & 100 & 0 & 0 & 7.35 & 0.125 & 0 & 20 \\
\hline $\begin{array}{c}\text { CPB-0.125-W/C } \\
10\end{array}$ & ST & 4.5 & 100 & 0 & 0 & 10 & 0.125 & 0 & 20 \\
\hline \multicolumn{10}{|c|}{ E. Effect of sulfate on the hydraulic conductivity } \\
\hline $\mathrm{CPB}$ & ST & 4.5 & 100 & 0 & 0 & 7.35 & 0.0 & 0 & 20 \\
\hline CPB-sulf. & ST & 4.5 & 100 & 0 & 0 & 7.35 & 0.0 & 25,000 & 20 \\
\hline CPB-SP-0 ppm & ST & 4.5 & 100 & 0 & 0 & 7.35 & 0.125 & 0 & 20 \\
\hline CPB-SP-sulf & ST & 4.5 & 100 & 0 & 0 & 7.35 & 0.125 & 25,000 & 20 \\
\hline
\end{tabular}

PCI: Portland cement type I; FA: fly ash; BFS: blast furnace slag; ST: silica tailings; NT: natural tailings; W/C ratio: water-to-cement ratio by weight; ppm: parts per million; * $4.5 \%$ binder content is used in the preparation of CPB in many mines; sulf.: sulfate. 


\subsection{Microstructural Analyses}

To understand the microstructural composition of the CPB with different treatments, thermal analyses (thermogravimetry (TG) and differential thermogravimetry (DTG)), X-ray diffraction (XRD), and mercury intrusion porosimetry (MIP) tests were conducted. The TG/DTG and XRD analyses were performed on cement paste samples with a W/C ratio of 2 (to mimic the high water content of $\mathrm{CPB}$ ). The cement paste samples were prepared in the same manner and condition as the $\mathrm{CPB}$ specimens. After reaching the desired curing period, the specimens were oven-dried under $45^{\circ} \mathrm{C}$ temperature until the mass becomes constant. The fully dried specimens were ground and analyzed accordingly. The thermogravimetric analyzer, SDT 2960 simultaneous DSC-TGA device (by TA Instruments, New Castle, DE, USA) was used for the TG/DTG test under a nitrogen atmosphere and heating ramp of $10{ }^{\circ} \mathrm{C} / \mathrm{min}$ to a maximum temperature of $1000^{\circ} \mathrm{C}$. The XRD test was carried out using Rigaku ultima IV diffractometer (by Rigaku Corp., Akishima, Japan) equipped with cross beam optics at a scanning rate of 1 degree per minute. In contrast, the MIP test was carried out on CPB specimens that were also oven-dried at $45^{\circ} \mathrm{C}$ temperature. The AutoPore III 9420 mercury porosimeter (by Micrometrcs, Norcross, GA, US) was used.

\section{Results and Discussions}

\subsection{Time Dependent Evolution of Hydraulic Conductivity of CPB}

The hydraulic conductivity of the CPB showed a consistent decrease for all samples over the curing period regardless of the tailings type and the superplasticizer content, as observed from Figure 2. The influence of curing time was largely dependent on the progression of cement hydration. Generally, the cement continues to undergo a chemical reaction in the presence of water leading to the production of compounds (e.g., ettringite, C-S-H, CH) that modify the pore structure of the CPB [43-46]. In effect, the spaces between the solid particles shrink as a result of the refinement and that would make the CPB less permeable. This can be noticed from the MIP graphs showing the distribution of pores in CPB specimens tested at different curing ages (Figure 3). Both incremental porosity and total pore volume were much higher in the CPB cured for 7 days. To further confirm the difference in the hydration products, cement paste samples with different curing times were subjected to thermal analyses. The TG/DTG diagrams of 7 days and 28 days samples are presented in Figure 4. The DTG graphs exhibit three distinct peaks corresponding to the proportion of the hydration products that decompose within specific temperature ranges. The first peak occurred between 100 and $200{ }^{\circ} \mathrm{C}$ and it was caused by the dehydration of hydrates, such as ettringite, gypsum, and C-S-H $[47,48]$. The second peak (between 400 and $500{ }^{\circ} \mathrm{C}$ ) was mainly as a result of the de-hydroxylation of portlandite (calcium hydroxide, $\mathrm{CH}$ ), while the third peak (between 650 and $750{ }^{\circ} \mathrm{C}$ ) was due to the decomposition of carbonated compounds as well as calcite $[46,47,49,50]$. The DTG graphs from Figure 4 indicate that there were many more hydration products (especially $\mathrm{CH}$ ) in the cement paste cured for 28 days than that cured for 7 days. This was reflected in the TG curves as there was about $80 \%$ of the 7 -day specimen remaining after reaching $1000{ }^{\circ} \mathrm{C}$ temperature as opposed to $70 \%$ of the 28 -day specimen. The reduction of hydraulic conductivity of CPB based on the progression of cement hydration has also been observed by other studies (e.g., $[21,24,25,51])$. 


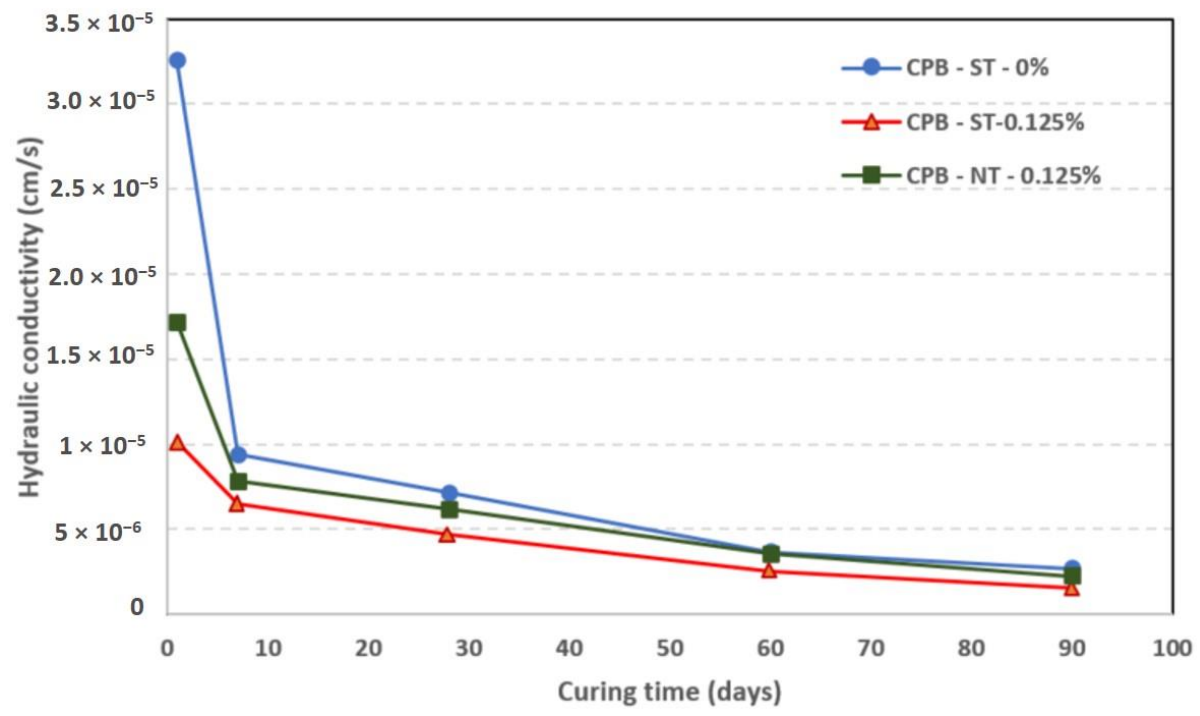

Figure 2. Evolution of hydraulic conductivity in $\mathrm{CPB}$ made with ST and NT.

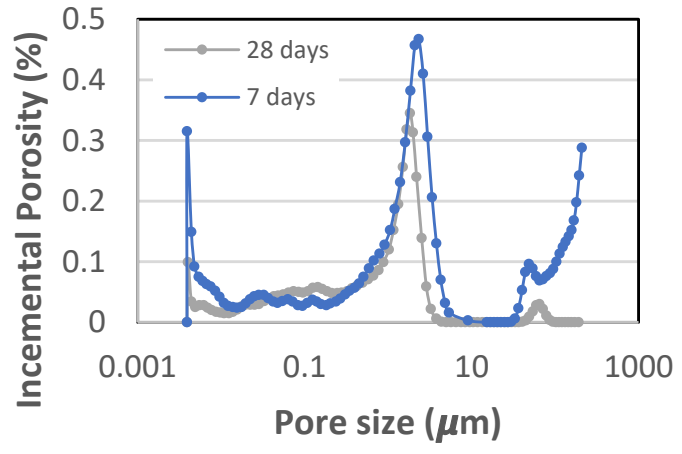

(a)

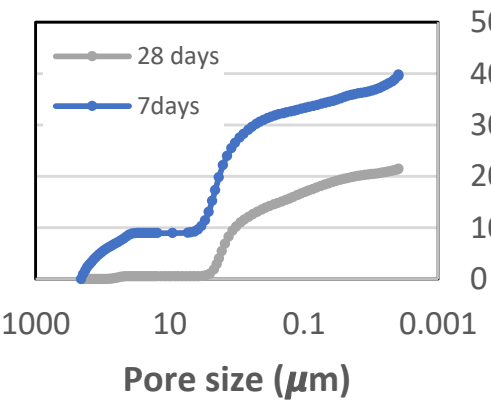

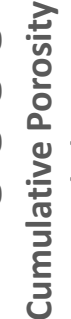

(b)

Figure 3. MIP graphs for CPB samples containing superplasticizer at different curing ages: (a) Pore size distribution (b) Cumulative pore volume.

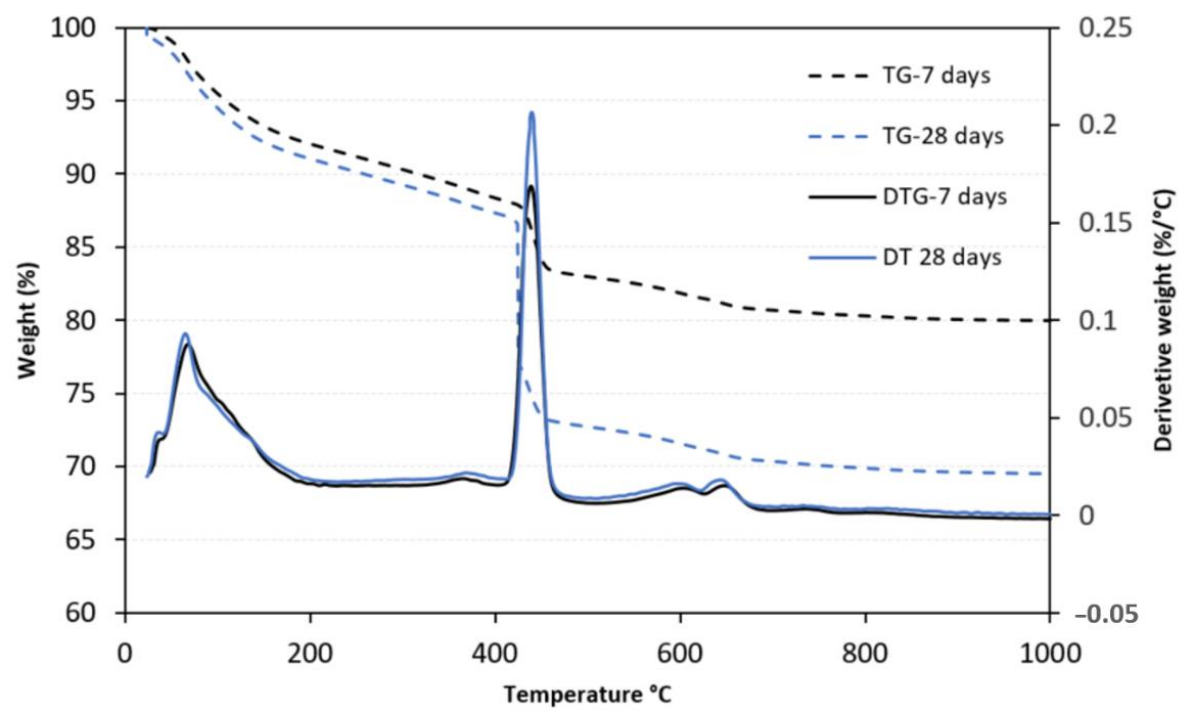

Figure 4. TG/DTG diagrams of pastes containing superplasticizer cured for 7 and 28 days. 
Beside the effect of curing time, Figure 2 also reveals that the hydraulic conductivity of the CPB decreases by replacing the ST with NT and by the addition of superplasticizer. The CPB-ST-0\% sample had hydraulic conductivity values of $3.25 \times 10^{-5}$ and $2.68 \times 10^{-6} \mathrm{~cm} / \mathrm{s}$ after 1 and 90 days, respectively, while the CPB-ST-0.125\% sample had $1.01 \times 10^{-5}$ and $1.51 \times 10^{-6} \mathrm{~cm} / \mathrm{s}$ after the same curing period. In other words, the hydraulic values of the CPB-ST-0.125\% sample after 1 and 90 days were approximately 3.2 and 1.8 times, respectively, lower than those of the CPB-ST-0\% sample. This decrease of the hydraulic conductivity of $\mathrm{CPB}$ due to the addition of superplasticizer was beneficial to the environmental performance of CPB, as explained earlier. The reduction can largely be attributed to the influence of the superplasticizer on particles' mobility and cement hydration. When used in cementitious materials, polycarboxylate-based superplasticizer molecules formed coated films around the solid particles, thereby preventing flocculation [34,52-54]. Although this is understood to retard the cement hydration reactions within few hours after mixing $[55,56]$ the superplasticizer intensifies the hydration by favoring ionic diffusion and nucleation of hydrates as time passes $[54,57,58]$. This claim is supported by the result of TG/DTG analysis on cement pastes containing $0 \%$ and $0.125 \%$ superplasticizer cured for 7 days as shown in Figure 5. It is evident that there are many more hydration products in the sample containing superplasticizer as it exhibits higher peaks. In addition to the improvement of cement hydration, the dispersion of the solid particles by the superplasticizer results in more intact structure due to self-consolidation [59-61]. This subsequently produces a $\mathrm{CPB}$ with less porosity and, therefore, less hydraulic conductivity as observed from the experimental results. The observation is supported by the MIP analysis on CPB samples containing $0 \%$ and $0.125 \%$ superplasticizer (Figure 6 ). The concentration of both coarse and fine pores was lower in the CPB containing superplasticizer. With respect to the tailing types, it was observed that the hydraulic conductivity of CPB specimens made of NT was significantly lower than that made of ST in the early age (1 and 7 days). Beyond 28 days of curing, there was relatively little or no difference between the hydraulic conductivity of the two samples. Because the particle size distribution of the two tailing types tailings were similar, the variation was likely associated with the mineralogical and chemical compositions. While the ST was completely nonreactive, the NT contained sulfide minerals, namely pyrite, pyrrhotite, and pyrrhotite (Table 2) as well as other minerals and sulfate ions that could influence the cement hydration. The sulfide minerals in the tailings produce sulfate compounds in the presence of oxygen and water $[39,62,63]$. The effect of sulfates on the cement hydration is explained in Section 3.5. In addition, there was a high percentage of chlorite in the NT (16.1\%) and many forms of these minerals are known to be expansive, capable of preserving permeability [64,65].

\subsection{Effect of Temperature on the Hydraulic Conductivity}

Each cemented backfill structure is unique with respect to its temperature. The temperature of the backfill is a function of several factors, such as the binder hydration heat, the initial temperature of the backfill components, the depth and geographic location of the mine [66]. Therefore, the impact of temperature on the hydraulic conductivity of CPB with superplasticizer was studied. Temperature was also observed to influence the hydraulic conductivity of the $\mathrm{CPB}$ containing superplasticizer. Figure 7 presents the evolution of the hydraulic conductivity of specimens prepared and cured at three different temperatures, 2,20 , and $35{ }^{\circ} \mathrm{C}$. Throughout the curing period of 90 days, the $\mathrm{CPB}$ cured at $35^{\circ} \mathrm{C}$ had the least hydraulic conductivity, followed by $20^{\circ} \mathrm{C}$, and then $2{ }^{\circ} \mathrm{C}$. This is similar to what was observed from other studies on CPB and other cementitious materials (e.g., [21,67-69], and thus, the presence of superplasticizer does not change the relationship. The MIP results (Figure 8 ) on CPB containing $0.125 \%$ superplasticizer and cured at 20 and $35{ }^{\circ} \mathrm{C}$ temperatures were in agreement with the assertion. The quantity of large pores as well as the cumulative pore volume in the $\mathrm{CPB}$ cured at $2{ }^{\circ} \mathrm{C}$ was much higher than that in the $\mathrm{CPB}$ cured at $35^{\circ} \mathrm{C}$. A more suitable parameter that can give a better understanding on why the hydraulic conductivity is different based on the pore distribution is the threshold diameter. 
According to Aligizaki [70], the threshold diameter, with respect to the mercury intrusion porosimetry, is the smallest pore size with geometric continuity throughout the sample, thereby allowing uninhibited intrusion. This pore diameter is approximated to be the point of inflexion on the cumulative porosity curve [70]. From Figure $8 b$, this diameter was approximately $3 \mu \mathrm{m}$ for the $20^{\circ} \mathrm{C}$ specimen and $0.08 \mu \mathrm{m}$ for the $35^{\circ} \mathrm{C}$ specimen. This means that the $35^{\circ} \mathrm{C}-\mathrm{CPB}$ has finer pore structure which translates to lower hydraulic conductivity.

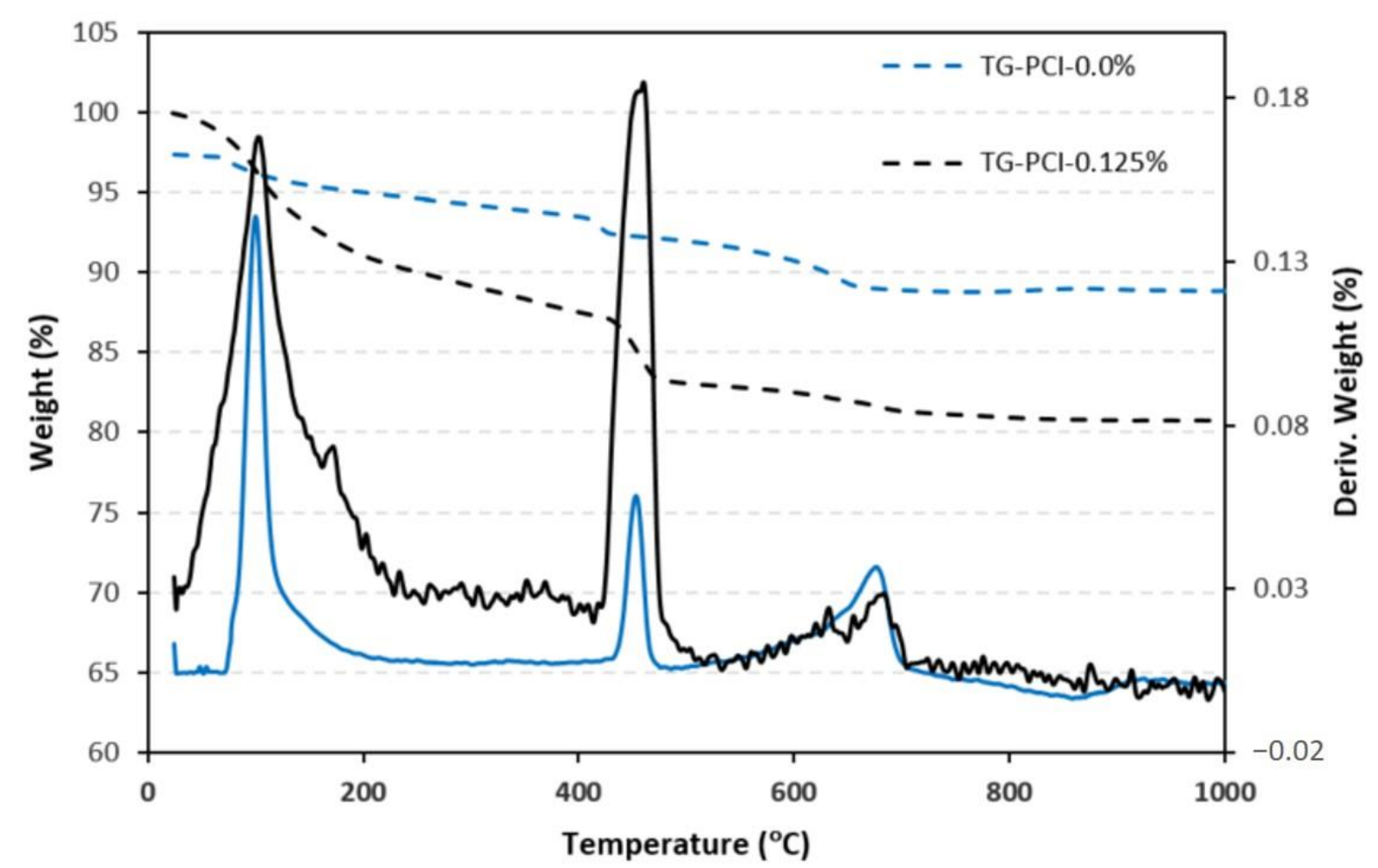

Figure 5. TG/DTG diagrams of 7-day cement pastes containing different superplasticizer contents.

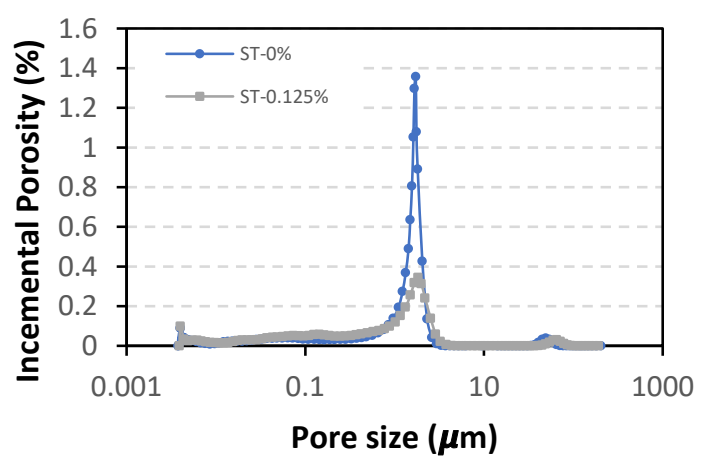

(a)

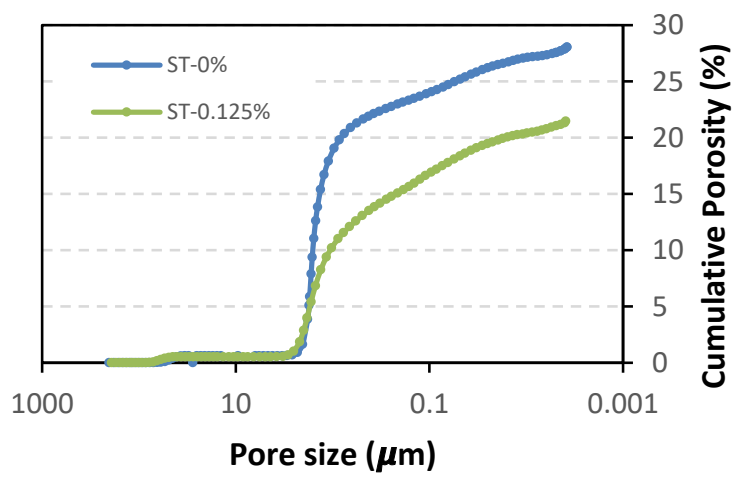

(b)

Figure 6. Effect of superplasticizer on the (a) pore size distribution and (b) cumulative pore volume in the CPB cured for 28 days. 


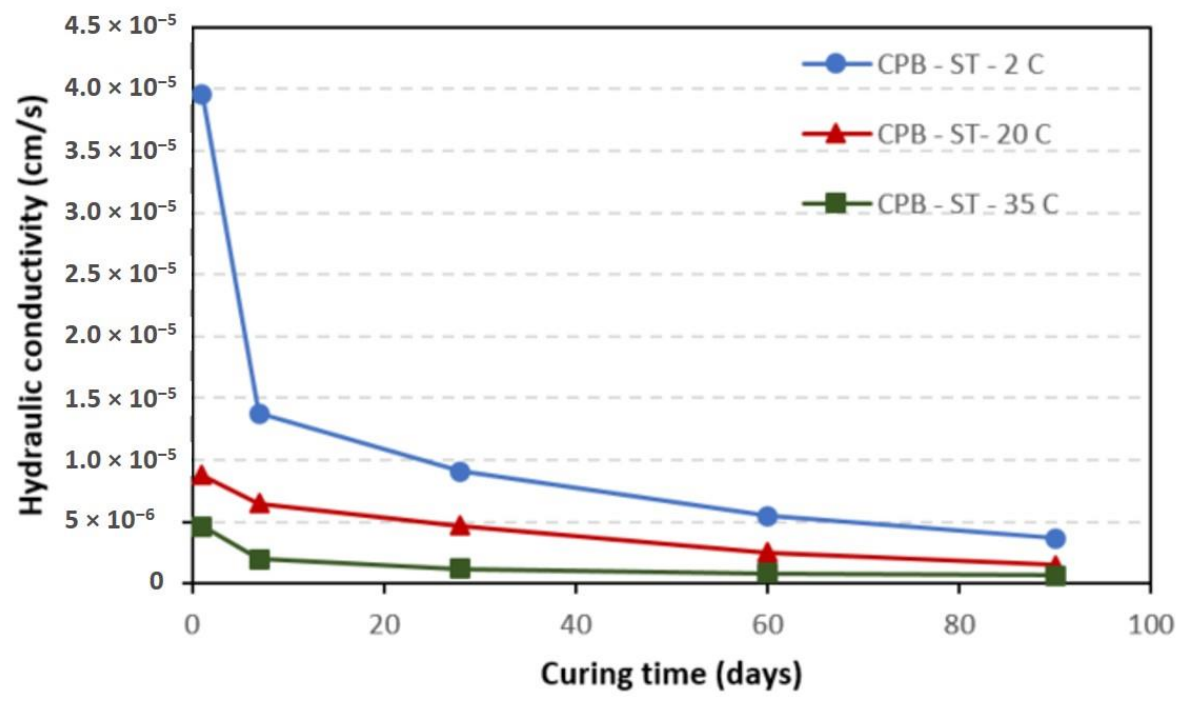

Figure 7. Effect of temperature on the hydraulic conductivity of $\mathrm{CPB}$ containing $0.125 \%$ superplasticizer.

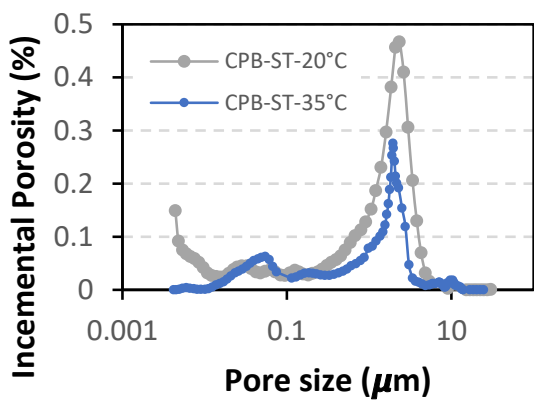

(a)

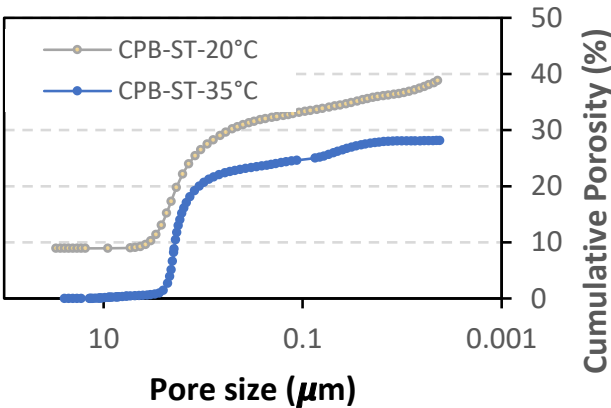

(b)

Figure 8. MIP graphs for $\mathrm{CPB}$ samples containing superplasticizer with different curing temperatures: (a) Pore distribution, (b) Cumulative pore volume.

\subsection{Effect of Binder Type on the Hydraulic Conductivity}

Because the replacement of $\mathrm{PCI}$ with pozzolans is a common practice in the backfilling industry, the effects of FA and BFS in CPB containing superplasticizer were investigated in this study. The evolution of the hydraulic conductivity of $\mathrm{CPB}$ with three blending ratios (100\% PCI; and 50/50 PCI/FA; 50/50 PCI/BFS) is shown in Figure 9. It can be noticed that the $\mathrm{CPB}$ containing PCI and FA had the highest hydraulic conductivity after 1 day and from 28 days onward. The sample containing PCI and BFS was the least permeable throughout the curing period. The reason for that can be attributed to the physical structure of the binders and the manner in which they react during the hydration process. Although BFS exhibited slow hydration reaction in the early age [71], its presence in the CPB could improve the hydraulic conductivity due to its filler effect. Slag had smaller particle size (with a specific surface greater than PCI, Table 3) and was therefore capable of filling the spaces between cement and tailings particles [72]. Furthermore, the pozzolanic effect of the $\mathrm{BFS}$ began once there was a sufficient amount of $\mathrm{CH}$ from $\mathrm{PCI}$ hydration. The reaction between $\mathrm{CH}$ and the BFS produced additional C-S-H gel which contributed to less porosity in the CPB [21,73]. On the other hand, FA did not act in the same way as the BFS on the overall hydration process. Its influence can be classified into dilution, physical, and chemical effects [74]. Replacement of PCI with the same quality of FA has been reported to increase the available water for hydration, which could subsequently improve the degree of cement hydration in concrete, a termed as dilution effect [74-76]. However, FA may also slow down the hydration due to the physical nature of its particles. Even though 
it has greater specific surface area than PCI (Table 3), calcium ions adsorb on its surface, thus lowering the overall ions to participate in the chemical reaction [77,78]. Similar to BFS, FA participates in the chemical reaction by reacting with the $\mathrm{CH}$ produced by cement hydration to form C-S-H gel [79]. Having the lowest percentage of $\mathrm{CaO}$ as shown in Table 3, this pozzolanic reaction produces less hydration products as compared to BFS in the long term. The XRD graphs presented in Figure 10 are in agreement with the above assertions. The CPB containing the blend of PCI and BFS had the largest quantities of C-S-H and ettringite indicating which facilitated the filling of pores which was the reason for its low hydraulic conductivity. These results show that replacement of cement with BFS would improve the environmental performance of $\mathrm{CPB}$ containing superplasticizer with respect to fluid transport ability.

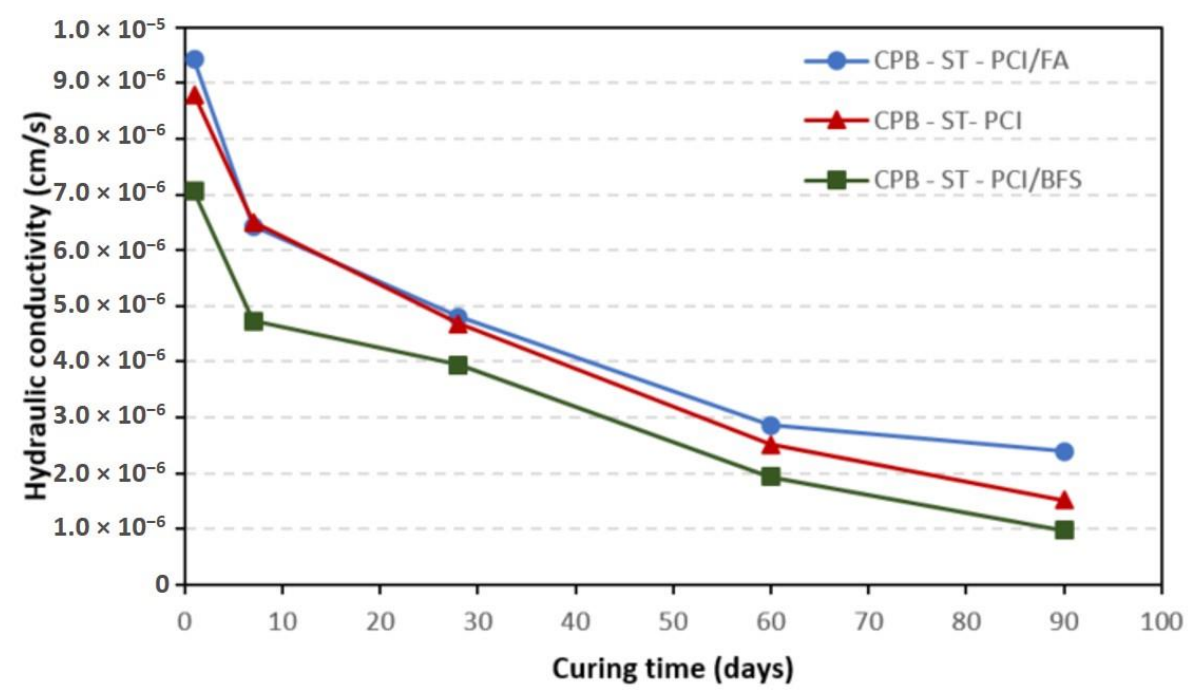

Figure 9. Effect of binder type on the hydraulic conductivity of $\mathrm{CPB}$ containing superplasticizer.

\subsection{Effect of Water-to-Cement Ratio on the Hydraulic Conductivity}

Superplasticizers are added in cementitious construction materials to improve workability and/or flowability without the need to increase the water content beyond what is required for optimum performance. Furthermore, CPB is always prepared with an excess of water (in terms of W/C) to enhance its flow ability. The optimal amount of water or $\mathrm{W} / \mathrm{C}$ used to prepare CPB is very variable and is a function of several factors (e.g., pumping and distribution system, tailing types). However, the combined superplasticizer and $\mathrm{W} / \mathrm{C}$ ratio on the hydraulic conductivity of $\mathrm{CPB}$ is unknown. Thus, the variation of the hydraulic conductivity of $\mathrm{CPB}$ with different $\mathrm{W} / \mathrm{C}$ ratios and constant amount of $\mathrm{PCI}$ and superplasticizer was investigated in this study. As shown in Figure 11, increasing the $\mathrm{W} / \mathrm{C}$ ratio increased the hydraulic conductivity of the $\mathrm{CPB}$. However, the increase was less than one order of magnitude. The reason of the aforementioned increase was due to the negative effect of excess water on the pore structure or porosity of $\mathrm{CPB}$ and cementitious material $[21,80,81]$. Indeed, a higher $\mathrm{W} / \mathrm{C}$ ratio implies a greater initial capillary pore content in the $\mathrm{CPB}$ specimen, i.e., in higher initial porosity and coarser pore structure of the backfill sample. This leads to slower and less complete filling of the CPB pores with binder hydration products, thus leading to higher hydraulic conductivity values due to coarser pore structure and higher porosity. This is evident in the pore distributions of $\mathrm{CPB}$ specimens with $\mathrm{W} / \mathrm{C}$ ratios of 5 and 7.35 shown in Figure 12. Thus, limiting the $\mathrm{W} / \mathrm{C}$ ratio in $\mathrm{CPB}$ to a required proportion is beneficial towards the improvement of its permeability, and thus enhancing its environmental performance. These conclusions and explanations also agree with the MIP results discussed by Fall et al. [21,64], which show that CPBs with a higher $\mathrm{W} / \mathrm{C}$ ratio have a higher overall porosity and coarser pore structure. 


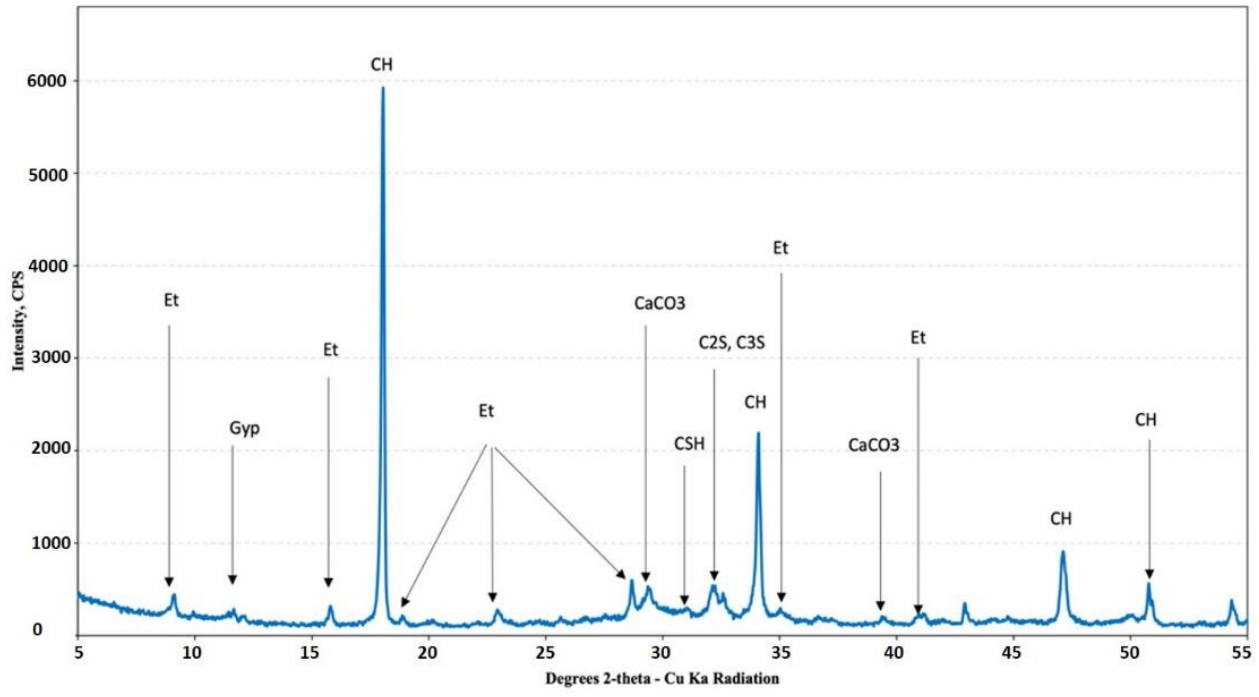

(a)

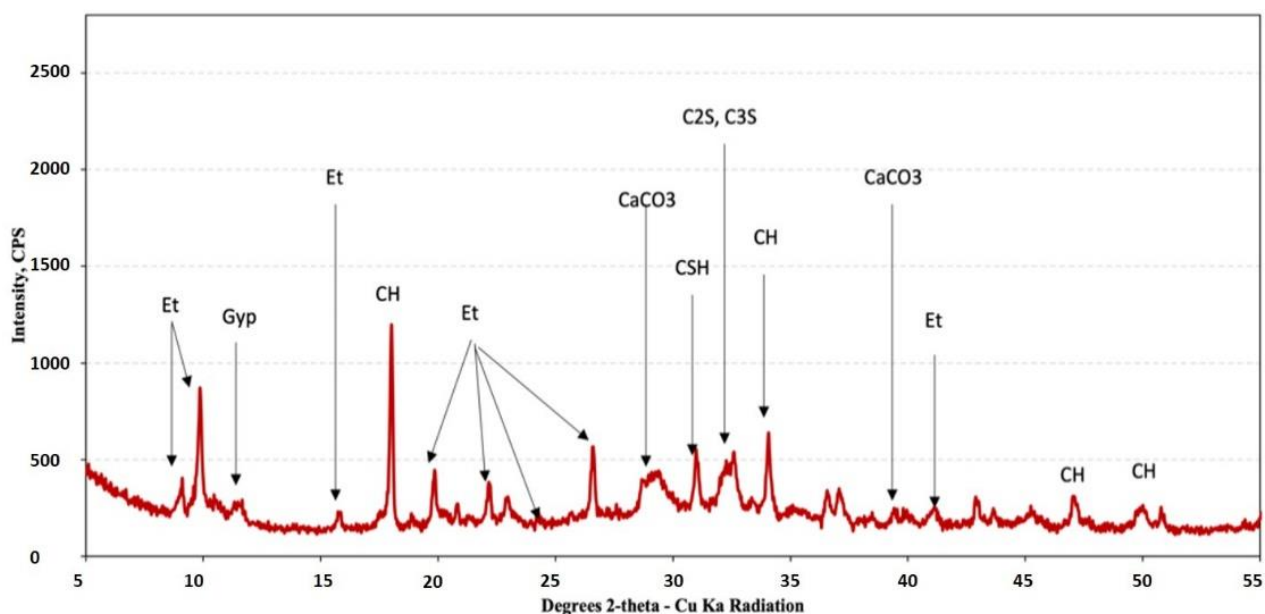

(b)

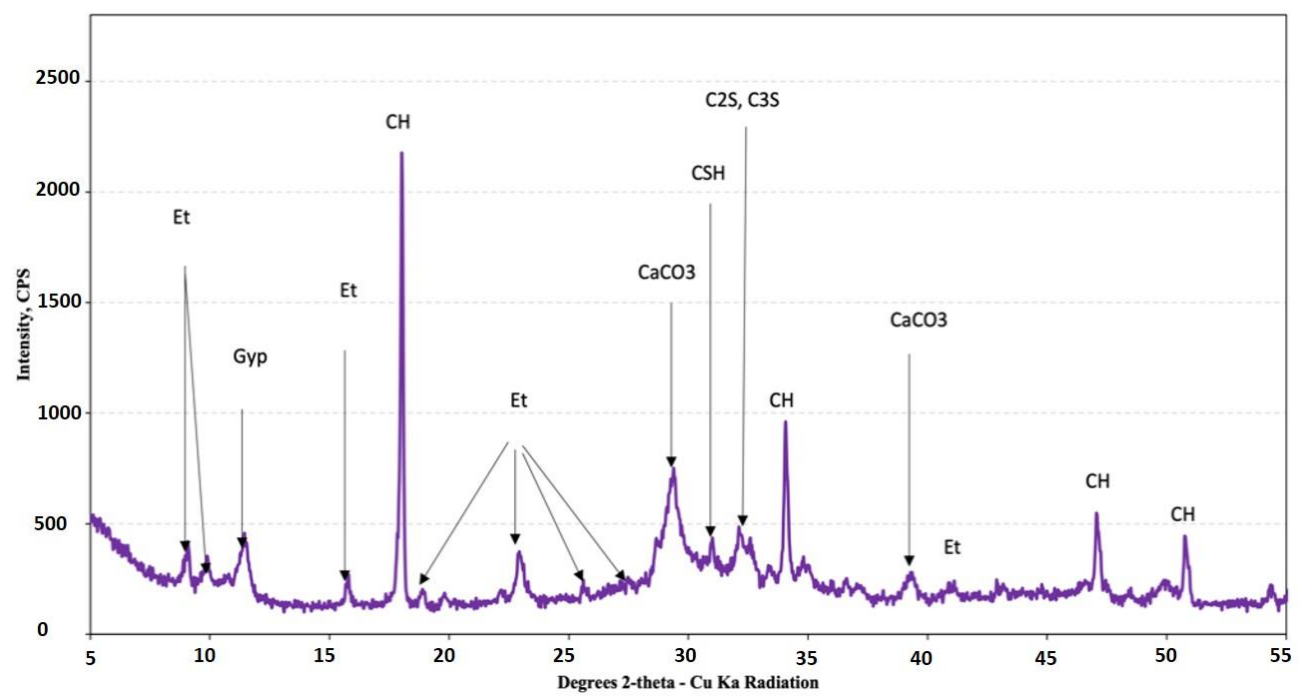

(c)

Figure 10. $\mathrm{XRD}$ analysis results for 28 days cement paste containing different binder types. (a) $\mathrm{CPB}$ containing $100 \%$ PCI (b) CPB containing 50:50 proportions of PCI and BFS (c) CPB containing 50:50 proportions of PCI and FA. 


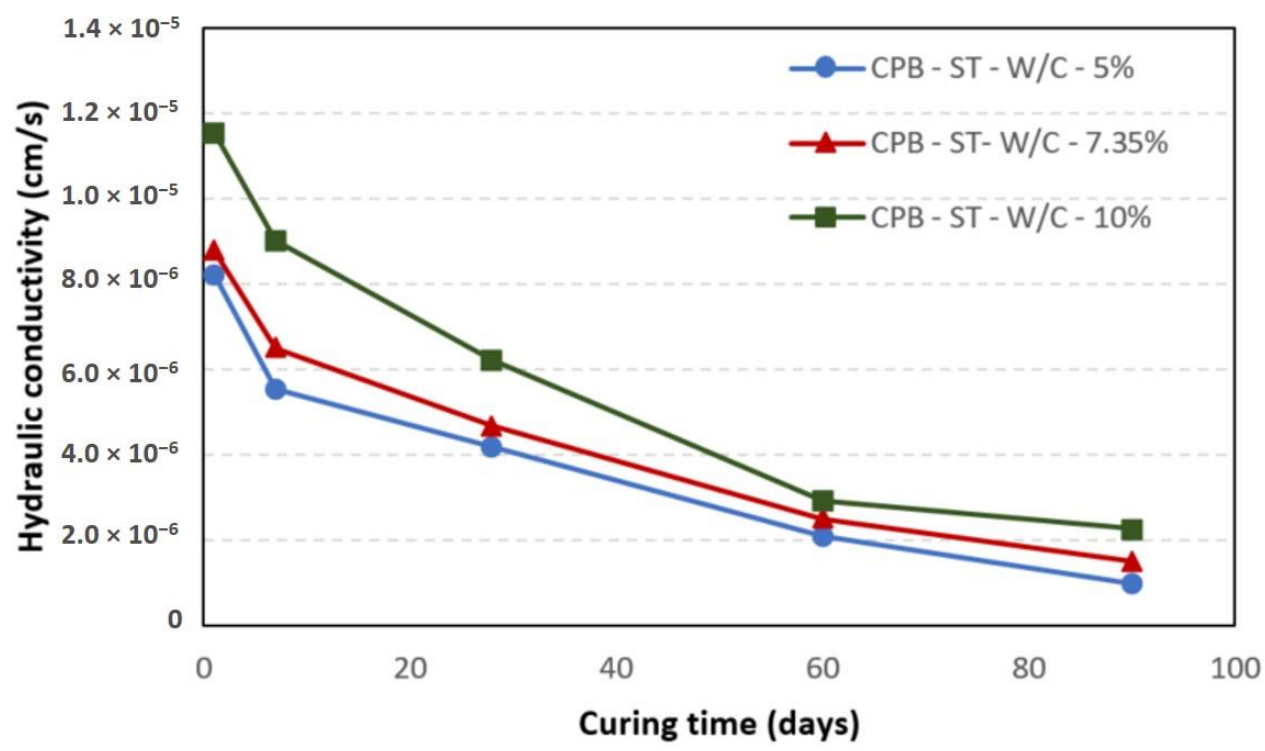

Figure 11. Effect of $\mathrm{W} / \mathrm{C}$ ratio on the hydraulic conductivity of $\mathrm{CPB}$ containing superplasticizer.

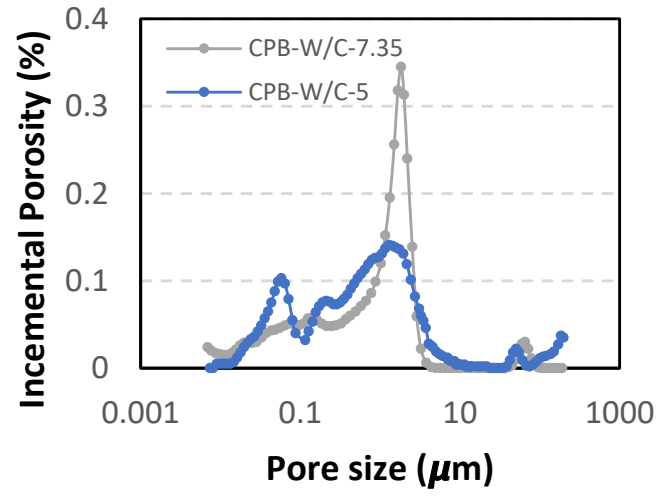

(a)

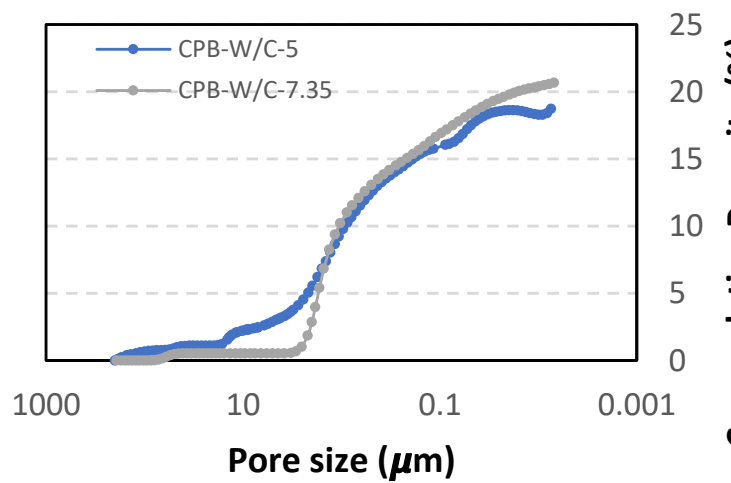

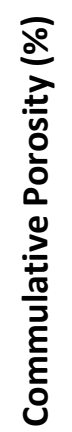

Figure 12. Effect of $\mathrm{W} / \mathrm{C}$ ratio on the (a) pore size distribution and (b) cumulative pore volume in the CPB samples containing superplasticizer.

\subsection{Effect of Sulfate Content on the Hydraulic Conductivity}

Sulfate is often found in $\mathrm{CPB}$, which can be generated through oxidation of the sulfide minerals in the tailings and mining processed water used as the mixing water for CPB [82]. Moreover, polycarboxylate-based superplasticizers are known to be sensitive to sulfate ions because both are adsorbed by the cement particles competitively $[36,37]$. Therefore, it is important to study the combined effect of the two compounds on $\mathrm{CPB}$. The hydraulic conductivity of $\mathrm{CPB}$ containing superplasticizer with 0 and 25,000 ppm sulfate contents is presented in Figure 13. The result indicates that the presence of sulfate in the CPB significantly reduces the hydraulic conductivity. This is likely due to the refinement of the pore structure of the $\mathrm{CPB}$ by the reaction of the sulfate with the binder and cement hydration products $(\mathrm{CH})$. Studies have shown that sulfate ions induce the precipitation of expansive minerals (gypsum and ettringite) as a result of the reaction between the sulfate ions and the cement components $\left(\mathrm{C}_{3} \mathrm{~A}\right)$ and hydration products (e.g., [25,83-85] ). These expansive minerals fill pores in the cemented matrix of the $\mathrm{CPB}$, thereby refining its pore structure and reducing its porosity. The pore distribution in the CPBs used in this study as seen from the MIP results in Figure 13 confirms that there is less porosity in the specimen containing sulfate. It is important to point out the little change in the hydraulic conductivity in the sulfated CPB from 60 to 90 days. There is a high tendency 
that the hydraulic conductivity of the CPB without sulfate would be less in the long term. This is expected because the excessive production of ettringite and gypsum due to sulfate eventually leads to cracks in the CPB [86-88], thus increasing the hydraulic conductivity.

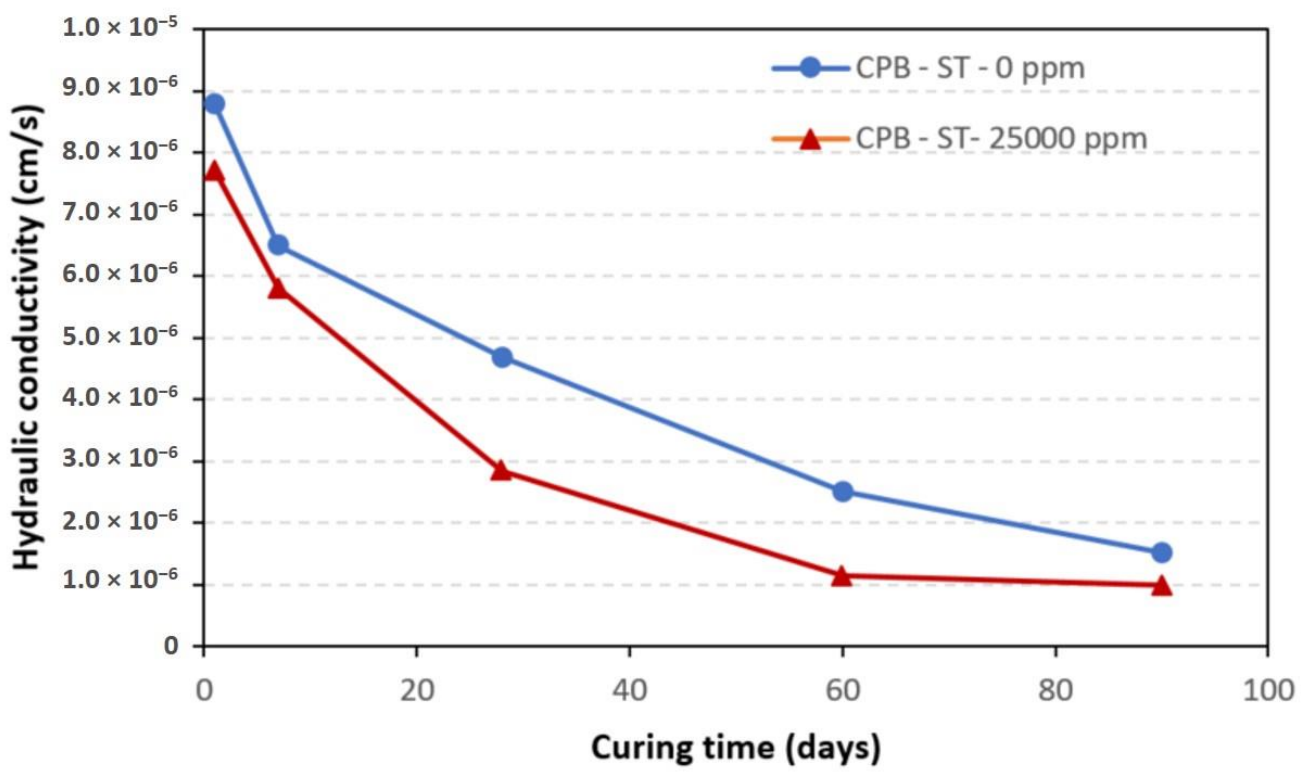

Figure 13. Effect of sulphate on the hydraulic conductivity of $\mathrm{CPB}$ containing superplasticizer.

\section{Summary and Conclusions}

This study highlighted the variations in the hydraulic conductivity of CPB containing polycarboxylate ether-based superplasticizer with different compositions and curing conditions. Vital conclusions drawn based on the results are summarized below.

1. The addition of ether-based superplasticizer decreased the hydraulic conductivity of the $\mathrm{CPB}$. The reduction was largely attributable to the influence of this superplasticizer on particles mobility and cement hydration. These results then imply that the addition of polycarboxylate ether-based superplasticizer to CPBs should result in an increase of the environmental performance of CPBs;

2. The hydraulic conductivity of the CPB decreased with curing time regardless of the mix composition, superplasticizer content, or curing condition. It generally decreased rapidly in the early age (up to 7 days) and continued slowly beyond that;

3. Increase in the curing temperature resulted in a significant decrease in the hydraulic conductivity. The behavior was largely due to faster cement hydration at high temperatures which led to more hydration products and finer pore structure;

4. Presence of sulfide minerals or sulphate ions in natural tailings influenced the hydraulic conductivity by inducing an excessive generation of expansive compounds that fill the pores in the $\mathrm{CPB}$;

5. Replacement of PCI with blast furnace slag was observed to improve the hydraulic conductivity significantly of the CPB containing ether-based superplasticizer. However, replacement with fly ash has an opposite effect although the marginal changes are small. These results suggest that the partial replacement of the Portland cement of CPB that contains polycarboxylate ether-based superplasticizer with Slag should improve its environmental performance;

6. A high water-to-cement ratio produced $\mathrm{CPB}$ with high hydraulic conductivity, implying that a lower water-to-cement ratio required for $\mathrm{CPB}$ with superplasticizer is beneficial towards the improvement of its permeability, and thus enhancing its environmental performance. 
Author Contributions: Conceptualization, M.F.; methodology, S.H. and M.F.; formal analysis, S.H.; investigation, S.H.; resources, M.F.; writing—original draft preparation, S.H.; writing-review and editing, M.F.; visualization, S.H.; supervision, M.F.; project administration, M.F.; funding acquisition, M.F. All authors have read and agreed to the published version of the manuscript.

Funding: This research was funded by Natural Sciences and Engineering Research Council of Canada (NSERC).

Data Availability Statement: All data, models, and code generated or used during the study appear in the submitted manuscript.

Acknowledgments: We would like to express appreciation to the Natural Sciences and Engineering Council of Canada (NSERC), the University of Ottawa, BASF Canada, and Lafarge Canada for their support towards this research.

Conflicts of Interest: The authors declare no conflict of interest.

\section{References}

1. Fridjonsson, E.O.; Hasan, A.; Fourie, A.B.; Johns, M.L. Pore structure in a gold mine cemented paste backfill. Miner. Eng. 2013, 53, 144-151. [CrossRef]

2. Cui, L.; Fall, M. An evolutive elasto-plastic model for cemented paste backfill. Comput. Geotech. 2016, 71, 19-29. [CrossRef]

3. Jiang, H.; Fall, M.; Cui, L. Freezing behaviour of cemented paste backfill material in column experiments. Constr. Build. Mater. 2017, 147, 837-846. [CrossRef]

4. Belibi Tana, A.E.; Yin, S.; Wang, L. Investigation on mechanical characteristics and microstructure of cemented whole tilings backfill. Minerals 2021, 11, 592. [CrossRef]

5. Ren, W.; Gao, R.; Zhang, Y.; Hou, M. Rheological properties of ultra-fine tailings cemented paste backfill under ultrasonic wave action. Minerals 2021, 11, 718. [CrossRef]

6. Shao, X.; Sun, W.; Li, X.; Wang, L.; Fang, Z.; Zhao, B.; Sun, J.; Tian, C.; Xu, B. Experimental study on the mechanical properties and failure characteristics of layered aeolian sand paste-like backfill-A case study from Shanghe coal mine. Minerals 2021, 11, 577. [CrossRef]

7. Wang, Y.; Fall, M.; Wu, A. Initial temperature-dependence of strength development and self-desiccation in cemented paste backfill that contains sodium silicate. Cem. Concr. Compos. 2016, 67, 101-110. [CrossRef]

8. Tang, Y.; Zheng, J.; Guo, L.; Zhao, Y. Effect of gypsum addition on the mechanical and microstructural performance of sulphiderich cemented paste backfill. Minerals 2021, 11, 283. [CrossRef]

9. Wang, S.; Wang, F.; Yin, D.; Jiang, T.; Zhang, Z. Experimental study on mechanical properties of paste backfill with flue-gas desulphurisation gypsum under combined action of dry-wet cycles and chloride erosion. Minerals 2021, 11, 882. [CrossRef]

10. Xu, X.; Sun, X.; Yao, W.; Wu, P.; Qiu, J.; Guo, Z.; Liu, N. Strength and ultrasonic characteristics of cemented paste backfill incorporating foaming agent. Minerals 2021, 11, 681. [CrossRef]

11. Abdul-Hussain, N.; Fall, M. Unsaturated hydraulic properties of cemented tailings backfill that contains sodium silicate. Eng. Geol. 2011, 123, 288-301. [CrossRef]

12. Grabinsky, M.; Bawden, W.; Simon, D.; Thompson, B. In situ properties of cemented paste backfill in an Alimak stope. Proc. GeoEdmonton 2008, 8, 790-796.

13. Skousen, J.G.; Sexstone, A.; Ziemkiewicz, P.F. Acid mine drainage control and treatment. Reclamation of drastically disturbed lands. In Agronomy Monographs; American Society of Agronomy: Madison, WI, USA, 2000.

14. Akcil, A.; Koldas, S. Acid Mine Drainage (AMD): Causes, treatment and case studies. J. Clean. Prod. 2006, 14, 1139-1145. [CrossRef]

15. Simate, G.S.; Ndlovu, S. Acid mine drainage: Challenges and opportunities. J. Environ. Chem. Eng. 2014, 2, 1785-1803. [CrossRef]

16. Vaughan, D.J.; Lennie, A.R. The iron sulphide minerals: Their chemistry and role in nature. Sci. Prog. 1991, 75, 371-388.

17. Gerasimov, A.; Kotova, E.; Ustinov, I. Applied Mineralogy of Anthropogenic Accessory Minerals. In International Congress on Applied Mineralogy; Springer: Cham, Germany, 2019; pp. 70-74.

18. Ren, M.; Wang, X. Accessory Mineral Analysis of Alkali-rich Granite from Gejiu Tin District. Microsc. Microanal. 2019, 25, 2322-2323. [CrossRef]

19. Jacobs, J.A.; Testa, S.M. Acid Mine Drainage, Rock Drainage, and Acid Sulfate Soils: Causes, Assessment, Prediction, Prevention, and Remediation; John Wiley \& Sons: Hoboken, NJ, USA, 2014.

20. Jennings, S.R.; Blicker, P.S.; Neuman, D.R. Acid Mine Drainage and Effects on Fish Health and Ecology: A Review; Reclamation Research Group: Bozeman, MT, USA, 2008.

21. Abdul-Hussain, A.; Fall, M.; Su, G. Evolution of hydraulic and mechanical properties of gelfill. In Proceedings of the 14th PanAmerican Conference on Soil Mechanics and Geotechnical Engineering (PCSMGE), the 64th Canadian Geotechnical Conference (CGC), Toronto, ON, Canada, 2-6 October 2011.

22. Bull, A.; Fall, M. Temperature dependency of the release of Asernic from cemented paste backfill made with Portland cement. J. Environ. Manag. 2020, 269, 110772. [CrossRef] [PubMed] 
23. Fall, M.; Adrien, D.; Célestin, J.C.; Pokharel, M.; Touré, M. Saturated hydraulic conductivity of cemented paste backfill. Miner. Eng. 2009, 22, 1307-1317. [CrossRef]

24. Godbout, J.; Bussière, B.; Belem, T. Evolution of cemented paste backfill saturated hydraulic conductivity at early curing time. In Proceedings of the 60th Canadian Geotechnical Society Conference (OttawaGeo 2007), Ottawa, ON, Canada, 21-24 October 2007.

25. Pokharel, M.; Fall, M. Combined influence of sulphate and temperature on the saturated hydraulic conductivity of hardened cemented paste backfill. Cem. Concr. Compos. 2013, 38, 21-28. [CrossRef]

26. Veenstra, R.L.; Grabinsky, M.W.; Bawden, W.F.; Thompson, B.D. A numerical analysis of how permeability affects the development of pore water pressure in early age cemented paste backfill in a backfilled stope. In Proceedings of the Eleventh International Symposium on Mining with Backfill, Perth, Australia, 20-22 May 2014; Australian Centre for Geomechanics: Crawley, Australia, 2014; pp. 83-95.

27. Cihangir, F.; Akyol, Y. Mechanical, hydrological and microstructural assessment of the durability of cemented paste backfill containing alkali-activated slag. Int. J. Min. Reclam. Environ. 2018, 32, 123-143. [CrossRef]

28. Ke, X.; Zhou, X.; Wang, X.; Wang, T.; Hou, H.; Zhou, M. Effect of tailings fineness on the pore structure development of cemented paste backfill. Constr. Build. Mater. 2016, 126, 345-350. [CrossRef]

29. Yilmaz, E.; Belem, T.; Benzaazoua, M.; Bussière, B. Assessment of the modified CUAPS apparatus to estimate in situ properties of cemented paste backfill. Geotech. Test. J. 2010, 33, 351-362.

30. Mollah, M.Y.A.; Adams, W.J.; Schennach, R.; Cocke, D.L. A review of cement superplasticizer interactions and their models. Adv. Cem. Res. 2000, 12, 153-161. [CrossRef]

31. Kauppi, A.; Andersson, K.M.; Bergström, L. Probing the effect of superplasticizer adsorption on the surface forces using the colloidal probe AFM technique. Cem. Concr. Res. 2005, 35, 133-140. [CrossRef]

32. Gelardi, G.; Flatt, R.J. Working mechanisms of water reducers and superplasticizers. In Science and Technology of Concrete Admixtures; Woodhead Publishing: Thorston, UK, 2016; pp. 257-278.

33. Björnström, J.; Chandra, S. Effect of superplasticizers on the rheological properties of cements. Mater. Struct. 2003, 36, 685-692. [CrossRef]

34. Bravo, M.; de Brito, J.; Evangelista, L.; Pacheco, J. Superplasticizer's efficiency on the mechanical properties of recycled aggregates concrete: Influence of recycled aggregates composition and incorporation ratio. Constr. Build. Mater. 2017, 153, 129-138. [CrossRef]

35. Plank, J.; Hirsch, C. Impact of zeta potential of early cement hydration phases on superplasticizer adsorption. Cem. Concr. Res. 2007, 37, 537-542. [CrossRef]

36. Pourchet, S.; Liautaud, S.; Rinaldi, D.; Pochard, I. Effect of the repartition of the PEG side chains on the adsorption and dispersion behaviors of PCP in presence of sulfate. Cem. Concr. Res. 2012, 42, 431-439. [CrossRef]

37. Pameijer, C.H. Biocompatibility of luting cements for dental applications. In Biocompatibility of Dental Biomaterials; Woodhead Publishing: Thorston, UK, 2017; pp. 77-94.

38. ASTM C143/C143M-15a; Standard Test Method for Slump of Hydraulic-Cement Concrete. ASTM International: West Conshohocken, PA, USA, 2015. Available online: www.astm.org(accessed on 25 January 2017).

39. Aldhafeeri, A.; Fall, M.; Pokharel, M.; Pouramini, Z. Temperature dependency of the reactivity of cemented paste backfill. Appl. Geochem. 2016, 72, 10-19. [CrossRef]

40. Yilmaz, E.; Kesimal, A.; Deveci, H.; Ercikdi, B. The factors affecting the performance of paste backfill: Physical, chemical and mineralogical characterization. In Proceedings of the First Engineering Sciences Congress for Young Researcher (MBGAK'03), Istanbul, Turkey, 17-20 February 2003.

41. Archibald, J.F.; Chew, J.L.; Lausch, P. Use of ground waste glass and normal portland cement mixtures for improving slurry and paste backfill support performance. In 100th Annual General Meeting of the Canadian Institute of Mining; Metallurgy and Petroleum: Montreal, QC, Canada, 1998.

42. Hassani, F.; Archibald, J. Mine Backfill; CIM: Montreal, QC, Canada, 1998.

43. Ercikdi, B.; Kesimal, A.; Cihangir, F.; Deveci, H.; Alp, I. Cemented paste backfill of sulphide-rich tailings: Importance of binder type and dosage. Cem. Concr. Compos. 2009, 31, 268-274. [CrossRef]

44. Bullard, J.W.; Jennings, H.M.; Livingston, R.A.; Nonat, A.; Scherer, G.W.; Schweitzer, J.S. Mechanisms of Cement Hydration. Cem. Concr. Res. 2011, 41, 1208-1223. [CrossRef]

45. Marchon, D.; Flatt, R.J. Mechanisms of cement hydration. In Science and Technology of Concrete Admixtures; Woodhead Publishing: Thorston, UK, 2016.

46. Li, W.; Fall, M. Strength and self-desiccation of slag-cemented paste backfill at early ages: Link to initial sulphate concentration. Cem. Concr. Compos. 2018, 89, 160-168. [CrossRef]

47. Zhou, Q.; Glasser, F.P. Thermal stability and decomposition mechanisms of ettringite at $<120{ }^{\circ} \mathrm{C}$. Cem. Concr. Res. 2001, 31, 1333-1339. [CrossRef]

48. Pane, I.; Hansen, W. Investigation of blended cement hydration by isothermal calorimetry and thermal analysis. Cem. Concr. Res. 2005, 35, 1155-1164. [CrossRef]

49. Gabrovšek, R.; Vuk, T.; Kaučič, V. Evaluation of the hydration of Portland cement containing various carbonates by means of thermal analysis. Acta Chim. Slov. 2006, 53, 159-165.

50. Piqué, T.M.; Balzamo, H.; Vázquez, A. Evaluation of the hydration of portland cement modified with polyvinyl alcohol and nano clay. In Key Engineering Materials; Trans Tech Publications Ltd.: Bäch SZ, Switzerland, 2011; Volume 466, pp. 47-56. 
51. Ghirian, A.; Fall, M. Coupled behavior of cemented paste backfill at early ages. Geotech. Geol. Eng. 2015, 33, 1141-1166. [CrossRef]

52. Fernandez-Alvarez, J.M.; Duran, A.; Navarro-Blasco, I.Í.; Lanas, J.; Sirera, R.; Alvarez, J.I. Influence of nanosilica and a polycarboxylate ether superplasticizer on the performance of lime mortars. Cem. Concr. Res. 2013, 43, 12-24. [CrossRef]

53. Wu, Q.; An, X.; Liu, C. Effect of polycarboxylate-type superplasticizer on the paste fluidity based on the water film thickness of flocs. Sci. China Technol. Sci. 2014, 57, 1522-1531. [CrossRef]

54. Haruna, S.; Fall, M. Time-and temperature-dependent rheological properties of cemented paste backfill that contains superplasticizer. Powder Technol. 2020, 360, 731-740. [CrossRef]

55. Lothenbach, B.; Winnefeld, F.; Figi, R. The influence of superplasticizers on the hydration of Portland cement. In Proceedings of the 12th ICCC, Montreal, QC, Canada, 9-12 July 2007; pp. W1-W5.03.

56. Zhang, Y.R.; Kong, X.M.; Lu, Z.B.; Lu, Z.C.; Hou, S.S. Effects of the charge characteristics of polycarboxylate superplasticizers on the adsorption and the retardation in cement pastes. Cem. Concr. Res. 2015, 67, 184-196. [CrossRef]

57. Puertas, F.; Santos, H.; Palacios, M.; Martínez-Ramírez, S. Polycarboxylate superplasticiser admixtures: Effect on hydration, microstructure and rheological behaviour in cement pastes. Adv. Cem. Res. 2005, 17, 77-89. [CrossRef]

58. He, Y.; Zhang, X.; Shui, L.; Wang, Y.; Gu, M.; Wang, X.; Peng, L. Effects of PCEs with various carboxylic densities and functional groups on the fluidity and hydration performances of cement paste. Constr. Build. Mater. 2019, 202, 656-668. [CrossRef]

59. Arezoumandi, M.; Volz, J.S. A comparative study of the mechanical properties, fracture behavior, creep, and shrinkage of high-volume fly ash concrete. J. Sustain. Cem.-Based Mater. 2013, 2, 173-185. [CrossRef]

60. Zhang, Y.; Kong, X. Influences of superplasticizer, polymer latexes and asphalt emulsions on the pore structure and impermeability of hardened cementitious materials. Constr. Build. Mater. 2014, 53, 392-402. [CrossRef]

61. Vakhshouri, B.; Nejadi, S. Compressive strength and mixture proportions of self-compacting lightweight concrete. Comput. Concr 2017, 19, 555-566. [CrossRef]

62. Elberling, B.; Nicholson, R.V. Field determination of sulphide oxidation rates in mine tailings. Water Resour. Res. 1996, 32, 1773-1784. [CrossRef]

63. Tariq, A.; Nehdi, M. Developing durable paste backfill from sulphidic tailings. In Proceedings of the Institution of Civil EngineersWaste and Resource Management; Thomas Telford Ltd.: London, UK, 2007; Volume 160, pp. 155-166.

64. Silvester, E.J.; Bruckard, W.J.; Woodcock, J.T. Surface and chemical properties of chlorite in relation to its flotation and depression. Miner. Processing Extr. Metall. 2011, 120, 65-70. [CrossRef]

65. Kennedy, M. Petrophysical Properties. In Developments in Petroleum Science; Elsevier: Amsterdam, The Netherlands, 2015; Volume 62, pp. 21-72.

66. Fall, M.; Célestin, J.C.; Pokharel, M.; Touré, M. A contribution to understanding the effects of temperature on the mechanical properties of cemented mine backfill. Eng. Geol. 2010, 14, 397-413. [CrossRef]

67. Wu, D.; Cai, S.J. Coupled effect of cement hydration and temperature on hydraulic behavior of cemented tailings backfill. J. Cent. South Univ. 2015, 22, 1956-1964. [CrossRef]

68. Palou, M.T.; Kuzielová, E.; Žemlička, M.; Boháč, M.; Novotný, R. The effect of curing temperature on the hydration of binary Portland cement. J. Therm. Anal. Calorim. 2016, 125, 1301-1310. [CrossRef]

69. Liu, B.; Luo, G.; Xie, Y. Effect of curing conditions on the permeability of concrete with high volume mineral admixtures. Constr. Build. Mater. 2018, 167, 359-371. [CrossRef]

70. Aligizaki, K.K. Pore Structure of Cement-Based Materials: Testing, Interpretation and Requirements; Taylor \& Francis: London, UK, 2006.

71. Bouzoubaa, N.; Foo, S. Use of fly ash and slag in concrete: A Best Practice Guide. Mater. Technol. Lab. MTL 2004, 16, 1-40.

72. Kumar, S.; Kumar, R.; Bandopadhyay, A.; Alex, T.C.; Kumar, B.R.; Das, S.K.; Mehrotra, S.P. Mechanical activation of granulated blast furnace slag and its effect on the properties and structure of portland slag cement. Cem. Concr. Compos. 2008, 30, 679-685. [CrossRef]

73. Niu, Q.; Feng, N.; Yang, J.; Zheng, X. Effect of superfine slag powder on cement properties. Cem. Concr. Res. 2002, 32, 615-621. [CrossRef]

74. Narmluk, M.; Nawa, T. Effect of fly ash on the kinetics of Portland cement hydration at different curing temperatures. Cem. Concr. Res. 2011, 41, 579-589. [CrossRef]

75. Zhang, Y.; Kong, X.; Hou, S.; Liu, Y.; Han, S. Study on the rheological properties of fresh cement asphalt paste. Constr. Build. Mater. 2012, 27, 534-544. [CrossRef]

76. Wang, X.Y. Effect of fly ash on properties evolution of cement based materials. Constr. Build. Mater. 2014, 69, 32-40. [CrossRef]

77. Langan, B.W.; Weng, K.; Ward, M.A. Effect of silica fume and fly ash on heat of hydration of Portland cement. Cem. Concr. Res. 2002, 32, 1045-1051. [CrossRef]

78. Rahhal, V.; Talero, R. Influence of two different fly ashes on the hydration of Portland cements. J. Therm. Anal. Calorim. 2004, 78, 191-205. [CrossRef]

79. Papadakis, V.G. Effect of fly ash on Portland cement systems: Part II. High-calcium fly ash. Cem. Concr. Res. 2000, 30, 1647-1654. [CrossRef]

80. Al-Manaseer, A.A.; Onofrei, M.; Gray, M.N.; Shenton, B. The effect of silica fume and water/cement ratio on the hydraulic conductivity of cement-based grout. MRS Online Proc. Libr. Arch. 1990, 212, 433-440. [CrossRef] 
81. Shamsai, A.; Peroti, S.; Rahmani, K.; Rahemi, L. Effect of water-cement ratio on abrasive strength, porosity and permeability of nano-silica concrete. World Appl. Sci. J. 2012, 17, 929-933.

82. Xiao, B.; Fall, M.; Roshani, A. Towards understanding the rheological properties of Slag-Cemented paste backfill. Int. J. Min. Reclam. Environ. 2020, 35, 268-290. [CrossRef]

83. Bellmann, F.; Möser, B.; Stark, J. Influence of sulfate solution concentration on the formation of gypsum in sulfate resistance test specimen. Cem. Concr. Res. 2006, 36, 358-363. [CrossRef]

84. Fall, M.; Benzaazoua, M. Modeling the effect of sulphate on strength development of paste backfill and binder mixture optimization. Cem. Concr. Res. 2005, 35, 301-314. [CrossRef]

85. Chen, X.; Shi, X.; Zhou, J.; Du, X.; Chen, Q.; Qiu, X. Effect of overflow tailings properties on cemented paste backfill. J. Environ. Manag. 2019, 235, 133-144. [CrossRef] [PubMed]

86. Roshani, A.; Fall, M.; Kennedy, K. Impact of drying on geo-environmental properties of mature fine tailings pre-dewatered with super absorbent polymer. Int. J. Environ. Sci. Technol. 2017, 14, 453-462. [CrossRef]

87. Li, W.; Fall, M. Sulphate effect on the early age strength and self-desiccation of cemented paste backfill. Constr. Build. Mater. 2016, 106, 296-304. [CrossRef]

88. Fang, K.; Fall, M. Chemically induced changes in the shear behaviour of interface between rock and tailings backfill undergoing cementation. Rock Mech. Rock Eng. 2019, 52, 3047-3062. [CrossRef] 